\title{
ПСИХОЛОГІЧНІ ОСОБЛИВОСТІ ПРОЯВУ СОРОМ'ЯЗЛИВОСТІ У ДІТЕЙ МОЛОДШОГО ДОШКІЛЬНОГО ВІКУ
}

\author{
Оксана Бондарчук \\ аспірантка кафедри теоретичної та консультативної психології \\ Національний педагогічний університет імені М. П. Драгоманова \\ 01601, Україна, м. Київ, вул. Пирогова, 9 \\ bondarchuk_oxana@email.ua, https://orcid.org/0000-0001-6976-6889
}

\begin{abstract}
Анотація
У статті здійснено теоретичний аналіз проблеми прояву та розвитку сором'язливості у дітей молодшого дошкільного віку, експериментально проаналізовано психологічні детермінанти особистісної сором'язливості у 3-4 річному віці. Теоретичне дослідження продемонструвало, що сором'язливість $є$ різносторонньою якістю особистості, яка зазвичай асоціюється із замкнутістю, невпевненістю, боязливістю, соромом. Дуже часто ранній прояв дитячої сором'язливості залишається непомітним та ототожнюється 3 інтровертованістю, несміливістю, тривожністю.

Серед чинників появи особистісної сором'язливості у дитячому дошкільному віці називають недостатній розвиток комунікативних знань і вмінь, копіювання поведінки одного з членів сім'ї, поведінкову скутість, постійне відчуття тривоги, негативний образ власного «Я».

Аналіз психологічних джерел дозволив виділити такі компоненти особистісної сором'язливості молодшого дошкільника: емоційно-оцінний, поведінковий i комунікативний. Ці складові активно розвиваються під час психофізіологічного дозрівання дитини та здійснюють взаємовплив на формування іiї самооцінки. Важливого значення у цей віковий період набуває також процес автономії, коли дитина починає робити перші самостійні кроки у дорослому світі, намагаючись продемонструвати особистісне «Я». Беззаперечного значення набуває й гармонійний емоційний розвиток молодшого дошкільника, під час якого формується емоційне самоставлення до себе, однолітків і дорослих, а негативний досвід взаємодії може слугувати основою майбутньої недовірливої поведінки дитини. Також варто зазначити, що психологічною особливістю особистісної сором'язливості у молодшому дошкільному віці $є$ майбутня проєкція негативної оцінки оточення і переживання почуття дискомфорту в присутності сторонніх людей.
\end{abstract}

Ключові слова: сором'язливість, особистість, дошкільник, самооцінка, соціальна тривога, автономність.

\section{Вступ}

Швидкі зміни у соціальному середовищі та, як наслідок, інтенсивна динаміка розвитку сучасної людини висуває новітні вимоги до розвитку і виховання молодої особистості XXI століття, яка $\epsilon$ самостійною, креативною, комунікабельною, мотивованою, здатною досягати успіху та володіє розвинутими соціальними навичками. 
Занадто високі запити суспільства роблять виклик не лише державній освітній політиці, орієнтуючи останню на всебічний розвиток дитини починаючи з немовлячого віку, а й молодшому дошкільнику. Інтенсивне життя маленької особистості, активний психічний розвиток можуть стати не лише поштовхом до пізнання навколишнього світу, а й переломним моментом багатьох уявлень, бажань і звичок, породжуючи формування негативних поведінкових установок, невпевненість у собі, недовіру до оточення. Відчуття такої «дитячої неповноцінності» спричинює бажання уникати контактів, стати непомітним для оточення, посилює тривогу, знижує самооцінку та є однією 3 причин розвитку особистісної сором'язливості.

Сором'язливість є однією з розповсюджених та маловивчених проблем особистості у сучасній психологічній науці та практиці. Психологічні концепції та підходи мають різний погляд на цей феномен. Так, 3. Фрейд, М. Кляйн, вивчаючи сором'язливість у руслі психоаналізу, вбачали у ній незадоволені інстинкті потреби, що призводять до дисбалансу між компонентами структури особистості. Г. Айзенк висловлював думку, що особистісна сором'язливість $є$ вродженою, біологічно зумовленою властивістю особистості, а послідовники біхевіористичної теорії досліджували цей феномен як реакцію страху людини на зовнішні, соціальні стимули. В сучасних теоретико-емпіричних дослідженнях учені схиляються до думки, що першопричиною виникнення сором'язливості $\epsilon$ специфічне розташування нейронів у префронтальних долях мозку, а неврологічна галузь медицини у своїх дослідженнях зробила акцент на тому, що це явище виникає у головному мозку людини та підтримується змінами у його діяльності впродовж тривалого часу, фіксуючи повторювальну модель поведінкових дій.

Розділилися також і погляди вчених-практиків щодо методології визначення поняття сором'язливості. На сьогодні існують такі тлумачення особистісної сором'язливості особистості, як: особистісна риса (К. Ізард); властивість особистості (В. Куніцина); соціально-набута модель поведінки; психофізіологічна особливість будови та функціонування ЦНС людини.

Попри різні визначення появи та розвитку сором'язливості, можна виокремити декілька спільних рис щодо розуміння її природи, які детально розглянув у своїх роботах Ф. Зімбардо. Це зв'язок сором'язливості з такими психологічними станами особистості як тривожність, страх, боязливість та інші негативні емоційні переживання, дискомфорт, виникнення труднощів під час комунікативної діяльності, занижена самооцінка, проблеми 3 самоповагою та негативний образ власної особистості, які беруть свій початок здебільшого у молодшому дитячому дошкільному віці, коли відбувається активний психічний розвиток і закладаються основи майбутньої поведінкової діяльності (Зимбардо, 1991; Зимбардо \& Рэдл, 2005).

Метою дослідження $€$ визначення психологічних особливостей прояву сором'язливості у дітей молодшого дошкільного віку. Завдання дослідження: 1) теоретичне вивчення проблеми прояву сором'язливості у молодших дошкільників; 2) визначення психологічних чинників прояву особистісної сором'язливості дітей 3-4 років; 3) емпіричне виявлення психологічних особливостей прояву сором'язливості у дітей молодшого дошкільного віку. 


\section{Методи дослідження}

Для розв'язання поставлених завдань i досягнення мети дослідження була розроблена програма, реалізація якої передбачала використання комплексу загальнонаукових методів: теоретичні: аналіз, синтез, класифікація, систематизація, порівняння i узагальнення теоретичних та експериментальних даних; емпіричні: спостереження, бесіда, тестування для виявлення рівня прояву особистісної сором'язливості у молодших дошкільників, вивчення продуктів діяльності дітей; методи математичної статистики: методи кореляційного аналізу залежних і незалежних вибірок, програмний пакет SPSS Statistics 2.0 для автоматизованої обробки одержаних даних.

Під час реалізації програми дослідження ми послуговувалися основними принципами дослідження психічного розвитку дошкільника, які є провідними у сучасній дитячій психології - принцип детермінізму, принцип об'єктивності, принцип причинності, принцип ретельності та регулярності, принципи гуманізму та системності й послідовності. Розкриваючи сутність перерахованих принципів, зазначимо, що принципи детермінізму та причинності $є$ необхідними під час вивчення умов, що зумовлюють виникнення у дитинидошкільника нових особистісних якостей та утворень у свідомості під час ії вікового розвитку. Водночас, психолог-практик повинен мати комплексний підхід до досліджуваного феномена, вміти не лише контролювати, а й прогнозувати розвиток сором'язливості у майбутньому, - це є одним з основних завдань принципу системності та послідовності. Принцип ретельності та регулярності дозволяє досліднику уважно спостерігати за процесом психічного розвитку молодшого дошкільника, залучаючи до експериментального дослідження вихователів і батьків, а також ретельно й обгрунтовано здійснювати підбір діагностичних методик. Принцип об’єктивності базується на врахуванні закономірностей, механізмів розвитку та особливостей психіки дитини. Важливого значення під час вивчення генези сором'язливості у дошкільників набуває принцип гуманізму, що втілюється у необхідності не зашкодити тактовній, чуйній поведінці з дитиною.

Програму дослідження було обгрунтовано на основних положеннях особистісноорієнтованого підходу 3 врахуванням вище згаданих принципів та включав наступні етапи: підбір валідних і надійних методик для вивчення сором'язливості у дітейдошкільнят 3-4 років; визначення критеріїв і рівнів розвитку сором'язливості у цей віковий період; виявлення психологічних особливостей і чинників формування дитячої сором'язливості у молодшому дошкільному віці.

У програмі дослідження було використано такі діагностичні методики: 1) карта спостережень Д. Скотта (адаптований варіант); 2) діагностика розвитку спілкування 3 однолітками (І. Орлова, В. Холмогорова); 3) проєктивна методика «Два будинки» (І. Вандвик, П. Екблад); 4) кольоровий тест Люшера; 5) методика «Страхи в будинках» (О. Захаров, М. Панфілова); 6) методика «Сходинки» В. Щура; 7) графічна методика М. Панфілової «Кактус».

Дослідницько-експериментальна робота виконувалася впродовж 2016-2018 років на базі закладу дошкільної освіти № 430 міста Києва, індивідуально 3 кожним досліджуваним. У програмі дослідження брала участь 131 дитина молодшого дошкільного віку. 


\section{Результати та дискусії}

Молодший дошкільний вік є тип віковим етапом розвитку, коли відбувається активне особистісне становлення та бурхливий розвиток психічних процесів у підростаючого покоління. Дошкільнята у цей час збагачують свої знання про навколишній світ, оволодівають специфічно людськими формами мислення та сприйняття, збагачують свій словниковий запас, вчаться спілкуватися з оточуючими, розвивають уяву, пам'ять, формують самооцінку та емоційно-поведінкову модель своєї майбутньої дорослої особистості. Швидкі психофізіологічні та соціальні зміни у житті молодшого дошкільника можуть стати як запорукою до досягнення успіху, так і мотивом уникання невдач i помилок, посилюючи відчуття дискомфорту й несміливості, та, породжуючи в майбутньому відчуття сором'язливості.

Появу особистісної сором'язливості у дитячі роки ототожнюють із відсутністю свободи спілкування, наявністю внутрішньої скутості у поведінці, неможливістю розвивати особистісний вроджений потенціал (О. Гаспарова, Ю. Орлова); відчуттям страху (К. Гросс) чи переживанням власного сорому і провини (В. Зеньківський), а О. Мішина охарактеризувала цей феномен як психічний стан відчуття спочатку фізичного, а згодом і морального дискомфорту (Белоусова, 2004; Галигузова, 2000; Журкина, 2014; Катаева, 2004; Мишина, 2012). Беззаперечно, перераховані означення щодо трактування сором'язливості у молодшому дошкільному віці завдають непоправної шкоди для гармонійного особистісного розвитку підростаючої дитини.

На сьогодні, у психологічній науці вчені обгрунтували такі детермінанти виникнення сором'язливості у дітей 3-4 років: 1) біологічні - генетична схильність, слабкість нервової системи тощо; 2) соціально-обумовлені - неприйняття дитини батьками, несприятливі сімейні обставини, гіперопіка, критичне ставлення до дій дитини; 3) культурно-історичні - вплив культурних вірувань, цінностей, звичаїв, норм моралі на формування особистісної сором'язливості; 4) особистісні - уникання однолітків, страхи, негативні емоційні переживання, відсутність ініціативності, інтровертованість, затримка мовленнєвому розвитку (Белоусова, 2004; Журкина, 2014; Зимбардо, 1991; Зимбардо \& Герриг, 2004; Зимбардо \& Рэдл, 2005; Chen, 2019; Stoltzfus, 2019).

Аналіз психологічних праць К. Ізарда, Г. Білоусової, Л. Галігузової, І. Іщенко, Є. Черняк та ін. (Белоусова, 2004; Галигузова, 2000; Зимбардо \& Рэдл, 2005; Изард, 1999; Chen, 2019; Stoltzfus, 2019) дозволив виділити такі компоненти особистісної сором'язливості у дітей молодшого дошкільного віку: афективно-оцінний, який представлений почуттям самотності, страху, тривожністю, легкою лякливістю, соромливістю; поведінкова складова виявляється у невпевненості під час ігрової діяльності, безініціативності, малорухливості, прагненні до самотності, тремтінні голосу, інтровертованості тощо; комунікативний компонент характеризується униканням вербального та невербального спілкування 3 однолітками чи вихователем, а також зніяковінням під час нього, обмеженістю або вибірковістю контактів, мовчазливістю, пасивністю. Варто також зазначити, що поведінка 3-4 річної сором'язливої дитини супроводжується почервонінням обличчя, відведенням очей, спітнілими долонями, зніяковілістю, напруженістю тіла, порушенням сердечного ритму (Sulika \& Eisenberg, 2013). 
Молодший дошкільний період є переломним моментом для дітей. У цей час діти починають поступово звільнятися від надмірного тиску батьківського виховання, продовжуючи здобувати свою автономність. Підтримка та заохочення дитячої самостійності батьками у цей час є запорукою розвитку позитивної саморегуляції (Alyssa \& Stephanie, 2019; Stoltzfus, 2019). Однак іноді цей процес супроводжується конфліктом між заповзятістю та відчуттям провини. На думку Е. Еріксона така суперечність може викликати негативні переживання і придушувати ініціативність маленьких сором'язливих особистостей, створюючи перешкоди у визначені мети діяльності та обрані шляхів іiі реалізації у дорослий період життя.

Сором’язливість молодшого дошкільника, який переживає кризу 3-х років, може негативно позначитися й на формуванні образу власного «Я» та самооцінки, яка у цей віковий період залежить від оцінки дорослого та є беззаперечною. Позитивне оцінювання та ставлення батьків до немовляти є запорукою розвитку високої самооцінки, а негативне - спричинює протилежний образ власного «Я». Ближче до 4 років важливого значення набуває спілкування з однолітками, яке стає більш зрозумілим, природним у порівнянні 3 дорослим, і відіграє свою роль у розвитку дитячої самосвідомості (Settea, Baldwinb, Zavaa, Baumgartnera \& Coplan, 2019). Дослідження Л. Галігузової продемонстрували, що низька самооцінка на цьому етапі розвитку може слугувати поштовхом до виникнення у майбутньому амбівалентного ставлення дитини до власного «Я» та особистості інших (Галигузова, 2000).

Ранній дошкільний вік є базисом у формуванні особистісного ставлення, а особливо емоційного. Л. Виготський зазначав, що у дошкільному періоді життя наша емоційна сфера відзначається бурхливим розвитком, емоції стають більш складними i набувають інтелектуалізованого характеру, а О. Запорожець припускав, що негативно сформоване емоційне ставлення до себе та оточуючих людей у дошкільника може спричинити труднощі під час засвоєння знань і вмінь (Вемь, 2000; Выготский, 2003).

I. Лапченко схилялася до думки, що емоційне ставлення, яке $\epsilon$ визначальним у дошкільному віці, має суб'єктивний і вибірковий характер і пов'язане зі значущими для дитини об'єктами. Це ставлення формується внаслідок переживань, викликаних певними людьми чи подіями та визначає поведінку дошкільника (Лапченко, 2006). Можна припустити що, різноманітні чинники (незнайоме оточення, вихователі, ситуації соціальної взаємодії та т. ін.), які слугують поштовхом до переживання сором'язливості, $\epsilon$ результатом минулого негативного дискомфорту і страху, який підтримувався позитивно схвальною реакцією дорослого чи, навпаки, осудом і сформував майбутню модель ставлення дитини на схожу ситуацію.

Сором'язливим дошкільникам властиво переживати відчуття соціальної тривоги та стурбованості у присутності незнайомих, а їх поведінка відзначається капризністю, знервованістю, соромливістю. Така тривога може бути наслідком переживання фрустрації соціальної потреби або ж розглядатися як комунікативний страх чи боязливість великого скупчення людей (Joan \& Luby, 2013; Nissa, Franz \& Copeland, 2014; Stoltzfus, 2019; Zdebik, Boivind, Battaglia \& Tremblaya, 2019). Чинниками появи соціальної тривожності у дітей 3-4 років можуть виступати: імітація батьківської поведінки, недостатньо позитивний емоційний контакт зі значущими дорослими, невідповідність їхніх наявних соціальних навичок і компетентностей (Богачкина, 2007; Катаева, 2004). 
Презентований кількісний та якісний аналіз результатів програми дослідження дозволив нам дослідити комунікативно-поведінковий та емоційно-оцінний компоненти особистісної сором'язливості у молодшому дошкільному віці. Для 67,7\% дітей молодшого дошкільного віку притаманна висока самооцінка. Така самооцінка на цьому віковому етапі першочергово визначається позитивним ставленням та оцінним схваленням дорослого, а особливо батьків, другорядне значення займає інтенсивність розвитку комунікацій з ровесниками. Молодші дошкільники з високою самооцінкою хвалькуваті, люблять бути у центрі уваги, активно спілкуються з однолітками, в ігровій діяльності прагнуть до лідируючих позицій, залучають інших до гри. 9,7\% дошкільнят мають середню самооцінку, що характеризується амбівалентністю особистісного ставлення, енергійністю, веселістю, прагненням до спілкування, зіштовхнувшись із перешкодами, можуть проявити нестійкість, орієнтуються на поведінку чи дії більш впевнених у собі однолітків, іноді можуть потребувати допомоги дорослого під час залучення до гри.

У кольоровій гамі тесту Люшера, діти з високим і середнім рівнем самооцінки надають перевагу червоному кольору, у першу четвірку також входять зелений, жовтий та синій кольори, що демонструє їх прагнення до досягнення мети, самоствердження, схвалення їх дій оточуючими, популярності серед однолітків. Такі молодші дошкільники відчувають захищеність, якщо оточені любов'ю, мають емоційну підтримку зі сторони дорослих. Емоції таких дітей залежать від речей, які викликають інтерес чи сильно хвилюють досліджуваних. Дошкільники прагнуть до пізнання оточуючої дійсності, намагаються бути помітними, зацікавити інших своєю особистістю. Дитячі дії та вчинки підпорядковані емоційній сфері, залежать від оцінки оточуючих, тому вони можуть бути занадто нав'язливі.

Аналіз проєктивної методики «Кактус» М. Панфілової засвідчив, що спілкуванню цієї групи дітей притаманні привітність і вмотивованість до продовження взаємодії.

За результатами методик «Два будинки» та «Страхи в будинках» виявлено, що соціальні зв'язки таких дітей відзначаються тісною гармонійною взаємодією з сім'єю, спостерігається довіра до друзів, вихователів, відсутність уникання контактів 3 незнайомими людьми. Серед соціально-опосередкованих страхів спостерігається острах залишитися самому $(54,17 \%)$, нападу зі сторони інших $(58,33 \%)$ чи покарання зі сторони батьків (41,67\%), страх перебування у центрі уваги інших людей мають лише 37,5\% дошкільників з високим і середнім рівнем самооцінки.

Комунікативна складова дітей з високою та середньою самооцінкою відзначається відкритістю до взаємодії з іншими людьми, комунікація є можливістю проявити себе, знайти нових друзів, вони легко вступають у спільну ігрову діяльність, можуть бути їі ініціаторами, зібрані у незнайомих ситуаціях. Результати спостереження також засвідчили, що діти з високим рівнем самооцінки характеризуються активною позицією у ставленні до іншої дитини, використанням мовних засобів, що закликають до спільної дії та супроводжуються використанням відповідних жестів, міміки, уважним спогляданням за поведінкою оточуючих. Діти із середніми показниками особистісного оцінювання звертають увагу на однолітків, цікавляться їхніми діями під час ігрової діяльності, але у спілкуванні займають пасивну позицію, не наважуються розпочати діалог і можуть спостерігати за грою інших зі сторони. 
Низьку самооцінку мають 22,6\% дітей молодшого дошкільного віку. Їх комунікативно-поведінкова сфера характеризується прагненням до уникання контактів, інтровертованістю, невпевненістю у собі, ознаками тривожності, неініціативні, уникають взаємодії з незнайомими чи малознайомими дорослими і дітьми. В ігровій діяльності ці діти мало відгукуються на пропозиції однолітків, прагнуть до самотності, не вступають до контакту з іншими дітьми першими, надають перевагу спостерігати за грою дітей здалеку.

За результатами проєктивного тесту Люшера та методики «Кактус» М. Панфілової встановлено, що такі діти емоційно дистанціюються від людей. Адже вони переживають дискомфорт та ізольованість у оточенні, в якому вони знаходяться; також їм не вистачає визнання дорослих та однолітків, їх позитивного оцінювання та заохочення. Дошкільники почуття впевненості компенсують шляхом неприступності, неможливості інших впливати на них, відстороненості від спільної діяльності. Їм властива тривожність, агресивність, стурбованість, боязливість, особистісне самоставлення негативно забарвлене. У спілкуванні чи ігровій діяльності вони проявляють ворожість, недовірливість до інших, прагнуть до створення емоційно захищеної атмосфери навколо себе.

Комунікативна сфера молодших дошкільників 3 низькою самооцінкою характеризується негативним ставленням до ровесників, можуть ображатися, плакати, переживають почуття боязливості, розгубленості, невпевненості у власних силах. Діти не ініціативні в ігровій діяльності, надають перевагу самостійній грі, споглядають за діями інших зі сторони.

Результати спостереження показали, що діти молодшого дошкільного віку мають труднощі у висловлюванні зацікавленості до співбесідника, не демонструють інтересу до дій ровесників, прагнуть до уникання будь-якої взаємодії з ними, спілкування нестійке, вербально скупе 3 помітними ознаками тривожності. Негативно вони реагують i на допомогу по догляду зі сторони вихователя, намагаються уникнути будь-якої взаємодії 3 ним. Турбота дорослого чи допомога ровесника вбачається ними як щось небезпечне, недоцільне й таке, що загрожує емоційній стабільності, викликає переживання, дискомфорт.

Серед соціально-опосередкованих страхів у 85,7\% дошкільників 3 низькою самооцінкою переважає страх взаємодії з незнайомими дорослими та дітьми, в 71,4\% досліджуваних наявний страх бути покинутим та лише у 42,86\% спостерігається страх перед покараннями й перебуванням у центрі уваги, наприклад, при публічному виступі. За допомогою методики «Два будинки» виявлено, що дошкільники також відзначили погані стосунки та недовіру до батька (42,86\%), друзів (57,14\%) і незнайомих людей $(28,57 \%)$.

За допомогою t-критерію Ст'юдента ( $\mathrm{t}$ крит. $=2,75$; при $\mathrm{p} \leq 0,01)$ виявлено, що у молодшому дошкільному віці сором'язливість характеризується очікуванням негативної оцінки інших людей ( $\mathrm{t}$ емп. =2,9), особливо під час надмірної уваги до дошкільника та дискомфортом у присутності незнайомих чи малознайомих людей ( $\mathrm{t}$ емп. $=3,7)$.

\section{Висновки}

Молодший дошкільний вік є тип етапом у житті особистості, коли відбувається стрімкий психічний розвиток і закладаються базисні основи майбутніх емоційноповедінкових реакцій. Переживання у цей час будь-яких складних, критичних ситуацій, на фоні кризи 3 річного віку, може слугувати поштовхом до формування тривожності, 
невпевненості, негативного самоставлення та зумовити появу сором'язливості. Помітити сором'язливого дошкільника неважко. Зазвичай ці діти уникають прямого контакту очей, червоніють, якщо помічають, що стали центром уваги інших, нервують, занурюються у власний світ, небалакучі та малоініціативні. Чинники такої сором'язливої поведінки дитини 3-4 років можуть бути, як вродженими (тип нервової системи), так і суспільноособистісними (гіперопіка, низька самооцінка, негативне емоційне самоставлення, невідповідність соціальних навичок віковому розвитку дитини, імітація поведінки дорослого тощо).

Результати емпіричного дослідження засвідчили, що молодші дошкільники, яким властива особистісна сором'язливість, схильні негативно оцінювати образ власного «Я», емоційно дистанціюватися від ровесників і дорослих, уникають будь-якої взаємодії 3 ними, вербально скупі, боязливі, тривожні, плаксиві у «загрозливих» для них ситуаціях, негативно сприймають турботу про себе, важко адаптуються у нових ситуаціях, в ігровій діяльності надають перевагу ролі спостерігача, а не активного учасника. Статистично підтверджено, що сором'язливість у молодшому дошкільному віці характеризується передчуттям привселюдної незадовільної оцінки оточуючих та особистісною незручністю у присутності незнайомих.

Подальші наші наукові дослідження будуть зорієнтовані на експериментальне вивчення особистісної сором'язливості дитини у середньому та старшому дошкільному віці, їі психологічні особливості та детермінанти прояву на цьому віковому етапі, а також розробку і впровадження програми з нівелювання дитячої сором'язливості у дошкільному віці, враховуючи динаміку прояву даного феномена та тенденції розвитку підростаючого покоління.

\section{Література}

1. Айзенк, Г.Ю. (1999). Структура личности. Санкт-Петербург: Ювента.

2. Белоусова, А.Б. (2004). Психологические детерминанты личностной застенчивости. (Автореф. дис. канд. психол. наук). Казань.

3. Богачкина, Н.А. (2007). Застенчивый мальиш. Москва: Научная книга.

4. Вемь, А. (2010). Застенчивость и как с ней бороться. Санкт-Петербург: Питер.

5. Выготский, Л.С.(2003). Психология развития ребенка. Москва: Эксмо-Пресс: Смысл.

6. Галигузова, Л.Н. (2000). Застенчивый ребенок. Дошкольное образование, 4, 116. Режим доступу: http://www.portal-slovo.ru/pre school education/36590.php.

7. Гурлєва, Т.С. (2011). Особливості розвитку автономності у дошкільному віці. Психолог дошкілля, 2, 9-13.

8. Застенчивость детей старшего дошкольного возраста (н. д.) Режим доступу: http://festi-val.1september.ru.

9. Зимбардо, Ф.Дж. (1991). Застенчивость. Москва: Педагогика.

10. Зимбардо, Ф.Дж., \& Герриг, Р.Дж. (2004). Психология и жизнь. Санкт-Петербург: Питер.

11. Зимбардо, Ф., \& Рэдл, Ш. (2005). Застенчивый ребенок. Москва: АСТ Астрель.

12. Изард, К.Э. (1999). Психология эмоций. Санкт-Петербург: Питер.

13. Катаева, Л.И. (2004). Работа психолога с застенчивыми детьми. Москва: Книголюб.

14. Кляйн, М.М. (1998). Некоторые теоретические выводы, касающиеся эмоциональной жизни ребенка. А.П. Поршенко \& И.Ю. Романов (Ред.), Психоанализ в развитии: сборник переводов (с. 5-107). Екатеринбург: Деловая книга.

15. Куницына, В.Н., Казаринова, Н.В., \& Погольша, В.М. (2001). Межсличностное общение. Санкт-Петербург: Питер. 
16. Лапченко, I.O. (2006). Емоиійне ставлення до себе та ровесників як чинник особистісного розвитку дитини дошкільного віку. (Автореф. дис. канд. психол. наук). Київ.

17. Мишина, Е.В. (2012). Застенчивый ребенок. Санкт-Петербург: Питер.

18. Фрейд, 3. (2016). Конечный и бесконечный анализ. Москва: Канон+.

19. Meuwissen, A.S., \& Carlson, S.M. (2019). An experimental study of the effects of autonomy support on preschoolers' self-regulation. Journal of Applied Developmental Psychology, 60, 11-23. https://doi.org/10.1016/j.appdev.2018.10.001

20. Chen, X. (2019). Culture and shyness in childhood and adolescence. New Ideas in Psychology, 53, 58-66. https://doi.org/10.1016/j.newideapsych.2018.04.007

21. Coplan, R.J., \& Armer, M. (2007). A «multitude» of solitude: A closer look at social withdrawal and nonsocial play in early childhood. Child Development Perspectives, 1(1), 26-32. https://doi.org/10.1111/j.1750-8606.2007.00006.x

22. Luby, J.M. (2013). Treatment of anxiety and depression in the preschool period. J Am Acad Child Adolesc Psychiatry, 52(4), 346-358. https://doi.org/ 10.1016/j.jaac.2013.01.011

23. Nissa, R., Franz, L., \& Copeland, W. (2014). Perceived family impact of preschool anxiety disorders. $J$ Am Acad Child Adolesc Psychiatry, 53(4), 437-446. https://doi.org/10.1016/j.jaac.2013.12.017

24. Settea, S., Baldwinb, D., Zavaa, F., Baumgartnera, E., \& Coplan, R. (2019). Shame on me? Shyness, social experiences at preschool, and young children's self-conscious emotions. Early Childhood Research Quarterly, 47, 229-238. https://doi.org/10.1016/j.ecresq.2018.12.012

25. Stoltzfus Grady, J. (2019). Parental gentle encouragement promotes shy toddlers' regulation in social contexts. $J$ Exp Child Psychol, 186, 83-98. https://doi.org/ 10.1016/j.jecp.2019.05.008

26. Strand, Paul S. (2008). Shyness and emotion-processing skills in preschoolers: A 6-Month Longitudinal Study. Wiley-Blackwell: Hoboken. Infant and Child Development, 17 (2), 109120.

27. Sulika, M., \& Eisenberg, N. (2013). Respiratory sinus arrhythmia, shyness, and effortful control in preschool-age children. Biol Psychol, 92(2), 241-248. https://doi.org/ 10.1016/j.biopsycho.2012.10.009

28. Zdebik, M., Boivind, M., Battaglia, M., \& Tremblaya, R. (2019). Childhood multitrajectories of shyness, anxiety and depression: Associations with adolescent internalizing problems. Journal of Applied Developmental Psychology, 64. https://doi.org/ 10.1016/j.appdev.2019.101050

\section{References}

1. Ayzenk, G.Y. (1999). Struktura lichnosti [Personality structure]. Sankt-Peterburg: Yuventa [in Russian].

2. Belousova, A.B. (2004). Psikhologicheskiye determinanty lichnostnoy zastenchivosti [Psychological determinants of personality shyness]. Extended abstract of Candidate's thesis. Kazan' [in Russian].

3. Bogachkina, N.A. (2007). Zastenchivyy malysh [Shy kid]. Moskva: Nauchnaya kniga [in Russian].

4. Vem', A. (2010). Zastenchivost' $i$ kak s ney borot'sya [Shyness and how to deal with it]. Sankt-Peterburg: Piter [in Russian].

5. Vygotskiy, L.S.(2003). Psikhologiya razvitiya rebenka [Child Development Psychology]. Moskva: Eksmo-Press: Smysl [in Russian].

6. Galiguzova, L.N. (2000). Zastenchivyy rebenok [Shy child]. Doshkol'noye obrazovaniye Preschool education, 4, 116. Retrieved from: http://www.portalslovo.ru/pre_school_education/36590.php [in Russian]. 
7. Gurlêva, T.S. (2011). Osoblivostí rozvitku avtonomností u doshkíl'nomu vítsí [Features of development of autonomy at preschool age]. Psikholog doshkillya-Preschool psychologist, 2, 9-13 [in Ukrainian].

8. Zastenchivost' detey ctarshego doshkol'nogo vozrasta [Shyness of older preschool children]. Retrieved from: http://festi-val.1september.ru [in Russian].

9. Zimbardo, F.Dzh. (1991). Zastenchivost' [Shyness]. Moskva: Pedagogika [in Russian].

10. Zimbardo, F.Dzh., \& Gerrig R.Dzh. (2004). Psikhologiya i zhizn' [Psychology and life]. Sankt-Peterburg: Piter [in Russian].

11. Zimbardo, F., \& Redl, Sh. (2005). Zastenchivyy rebenok [Shy child]. Moskva: AST Astrel' [in Russian].

12. Izard, K.E. (1999). Psikhologiya emotsiy [Psychology of emotions]. Sankt-Peterburg: Piter [in Russian].

13. Katayeva, L.I. (2004). Rabota psikhologa s zastenchivymi det'mi [The work of a psychologist with shy children]. Moskva: Knigolyub [in Russian].

14. Klyayn, M.M. (1998). Nekotoryye teoreticheskiye vyvody, kasayushchiyesya emotsional'noy zhizni rebenka [Some theoretical conclusions regarding the emotional life of a child]. In A. P. Porshenko \& I. Yu. Romanov (Eds.), Psikhoanaliz v razvitii: sbornik perevodov - Psychoanalysis in development: a collection of translations (s. 5-107). Yekaterinburg: Delovaya kniga [in Russian].

15. Kunitsyna, V.N., Kazarinova, N.V., \& Pogol'sha, V.M. (2001). Mezhlichnostnoye obshcheniye [Interpersonal communication]. Sankt-Peterburg: Piter [in Russian].

16. Lapchenko, Í.O. (2006). Yemotsíyne stavlennya do sebe ta rovesnikív yak chinnik osobistísnogo rozvitku ditini doshkíl'nogo víku [Emotional attitude towards oneself and peers as a factor of personal development of preschool children]. Extended abstract of Candidate's thesis. Kiîv [in Ukrainian].

17. Mishina, Ye.V. (2012). Zastenchivyy rebenok [Shy child]. Sankt-Peterburg: Piter [in Russian].

18. Freyd, Z. (2016). Konechnyy i beskonechnyy analiz [Finite and endless analysis]. Moskva: Kanon+ [in Russian].

19. Meuwissen, A.S., \& Carlson, S.M. (2019). An experimental study of the effects of autonomy support on preschoolers' self-regulation. Journal of Applied Developmental Psychology, 60, 11-23. https://doi.org/10.1016/j.appdev.2018.10.001

20. Chen, X. (2019). Culture and shyness in childhood and adolescence. New Ideas in Psychology, 53, 58-66. https://doi.org/10.1016/j.newideapsych.2018.04.007

21. Coplan, R.J., \& Armer, M. (2007). A «multitude» of solitude: A closer look at social withdrawal and nonsocial play in early childhood. Child Development Perspectives, 1(1), 26-32. https://doi.org/10.1111/i.1750-8606.2007.00006.x

22. Luby, J.M. (2013). Treatment of anxiety and depression in the preschool period. J Am Acad Child Adolesc Psychiatry, 52(4), 346-358. https://doi.org/ 10.1016/j.jaac.2013.01.011.

23. Nissa, R., Franz, L., \& Copeland, W. (2014). Perceived family impact of preschool anxiety disorders. J Am Acad Child Adolesc Psychiatry, 53(4), 437-446. https://doi.org/10.1016/j.jaac.2013.12.017

24. Settea, S., Baldwinb, D., Zavaa, F., Baumgartnera, E., \& Coplan, R. (2019). Shame on me? Shyness, social experiences at preschool, and young children's self-conscious emotions. Early Childhood $\quad$ Research 229-238. https://doi.org/10.1016/j.ecresq.2018.12.012

25. Stoltzfus Grady, J. (2019). Parental gentle encouragement promotes shy toddlers' regulation in social contexts. J Exp Child Psychol, 186, 83-98. https://doi.org/ 10.1016/j.jecp.2019.05.008.

26. Strand, Paul S. (2008). Shyness and emotion-processing skills in preschoolers: A 6-Month Longitudinal Study. Wiley-Blackwell: Hoboken. Infant and Child Development, 17 (2), 109-120. 
27. Sulika, M., \& Eisenberg, N. (2013). Respiratory sinus arrhythmia, shyness, and effortful control in preschool-age children. Biol Psychol, 92(2), 241-248. https://doi.org/ 10.1016/j.biopsycho.2012.10.009

28. Zdebik, M., Boivind, M., Battaglia, M., \& Tremblaya, R. (2019). Childhood multitrajectories of shyness, anxiety and depression: Associations with adolescent internalizing problems. Journal of Applied Developmental Psychology, 64. https://doi.org/ 10.1016/j.appdev.2019.101050

\title{
PSYCHOLOGICAL FEATURES OF MANIFISTATION OF SHYNESS IN CHILDREN OF PRIMARY SCHOOL AGE Oksana Bondarchuk
}

Postgraduate student of the Department of Theoretical and Counseling Psychology

National Pedagogical Dragomanov University

9, Pyrohov Str., Kyiv, Ukraine, 01601

bondarchuk oxana@email.ua, https://orcid.org/0000-0001-6976-6889

\begin{abstract}
The article presents a theoretical analysis of the problem of manifestation and development of shyness in young preschool children, experimentally analyzes the psychological determinants of personal shyness at the age of 3-4 years. Theoretical analysis of the study showed that shyness is a versatile quality of personality, which is usually associated with seclusion, uncertainty, timidity, shame. Very often the early manifestation of childhood shyness goes unnoticed and is identified with introversion, timidity, anxiety. Among the causes of child preschool shyness one can mention insufficient development of communicative knowledge and skills, copying the behavior of one of the family members, behavioral stiffness, constant anxiety, negative selfimage.

The analysis of psychological sources revealed the following components of preschool personal shyness: emotional-evaluative, behavioral and communicative. These components actively develop during the psychophysiological maturation of the baby and exert a mutual influence on the formation of his self-esteem. Also during this age it is important the process of autonomy, when the child begins to take the first independent steps in the adult world, trying to demonstrate personal self. Harmonious emotional development of a younger preschooler becomes very important during which emotional self-esteem and attitude to peers and adults are formed, and a negative experience of interaction may form the basis of a child's future distrustful behavior. It is also worth noting that a psychological feature of personal shyness at a young preschool age is a future projection of a negative evaluation of others and feelings of discomfort in the presence of strangers.
\end{abstract}

Keywords: shyness, personality, preschooler, self-esteem, social anxiety, autonomy.

Подано 14.01.2020

Рекомендовано до друку 01.02.2020 